The BMJ

Cite this as: BMJ2020;370:m3096 http://dx.doi.org/10.1136/bmj.m3096 Published: 05 August 2020

\section{Covid-19: Where are we on immunity and vaccines?}

As covid-19 vaccine trials begin to report early results and research papers on immunity shed more
light on the situation, Elisabeth Mahase looks at what we know so far Elisabeth Mahase

\section{Do the recent vaccine papers tell us anything new?}

There was a flurry of excitement last month when two new papers published in the Lancet outlined the early findings from two SARS-CoV-2 vaccine trials.

The first came from the University of Oxford $^{1}$ and reported that, in a phase I/II trial involving just over 1000 healthy adults ( 543 given the vaccine, 534 given the meningococcal conjugate vaccine as a control), the vaccine candidate induced strong antibody and $\mathrm{T}$ cell immune responses (up to day 56 ). They reported no serious adverse events.

The ChAdOx1 nCoV-19 vaccine uses an adenovirus vaccine vector and the genetic sequence for the SARS-CoV-2 spike protein. After the vaccine has been administered the spike protein is produced, which primes the immune system to recognise and attack the virus if the vaccinated person is infected in the future. The researchers, led by Sarah Gilbert, professor of vaccinology, have teamed up with AstraZeneca and have already begun phase III trials in England to determine efficacy, as well as in South Africa and Brazil. A US trial should begin later this year. ${ }^{2}$

The second paper came from researchers in China, who tested their non-replicating adenovirus type- 5 vectored vaccine (Ad5-nCoV) on 382 participants (who received either a high or low dose, while 126 people received a placebo). ${ }^{3}$ This vaccine candidate, developed with CanSino Biologics, uses a weakened human common cold virus to deliver genetic material that codes for the SARS-CoV-2 spike protein to the cells.

The researchers reported that, 28 days after vaccination, $95 \%$ of participants (241/253) in the high dose group and $91 \%(118 / 129)$ in the low dose group showed either T cell or antibody immune responses. The team said that, while the proportion of adverse reactions (such as fever, fatigue, or injection site pain) was considerably higher in vaccine recipients than in placebo recipients ( $72 \%$ in the high dose group, $74 \%$ in the low dose group, $37 \%$ in the placebo group), most adverse reactions were mild or moderate.

However, while both papers reported promising preliminary results and have provided some hope that at least one of these vaccines could be effective, we still do not know what level of immune response is needed to protect against the virus. That information is vital to determining whether a vaccine is effective.

\section{Is China giving an experimental vaccine to the military?}

Yes-the Chinese military will receive the $\mathrm{Ad}_{5}-\mathrm{nCoV}$ vaccine. China's military commission gave the vaccine a "military specially needed drug approval" on 25 June, said a statement from the drug company CanSino to the Hong Kong Stock Exchange, despite it not yet completing phase III trials. The approval will last one year. It said, "Data of clinical trials showed [a] good safety profile and high levels of humoral and cellular immune response. The overall clinical results indicate that the $\mathrm{Ad} 5$-nCoV has potential to prevent diseases caused by SARS-CoV-2."4

\section{Is Russia starting mass immunisation in October?}

The Russian government has announced that it will begin production of a vaccine in September and start mass immunisation in October. ${ }^{5}$ However, concerns have been raised over how the candidate vaccine has been tested, as no Russian studies are included on the World Health Organization's list of phase III trials. The vaccine has been developed by the Gamaleya Institute, Moscow, and uses two strains of adenovirus. The institute previously caused controversy after reports that it tested its vaccine on soldiers and that researchers dosed themselves during shortened human trials. Meanwhile, Canada, the UK, and the US have accused Russia of trying to steal vaccine research, although Russian officials have denied this. ${ }^{6}$

\section{What do we know about T cell immunity?}

We have heard a lot about antibodies over the past seven months, but they are only one part of the immune response. Scientists are now looking at another-T cells. Writing in The BMJ, experts explained that four types of $\mathrm{T}$ cells are of interest ${ }^{7}$ :

- T helper cells (CD4), which are responsible for cellular immunity and for helping B cells to produce neutralising antibodies;

- Cytotoxic or "killer” T cells (CD8), which directly kill infected cells; 
- Other T cells (including T-17 (Th17) cells), which drive the inflammatory responses that help to control infections; and

- Regulatory T cells, which help to contain the immune response, thereby preventing over-reaction and damage to tissues.

Some researchers are hopeful that T cells could provide durable protection against the virus. Speaking at a Science Media Centre briefing on T cell immunity, Daniel Altmann, professor of immunology at Imperial College London, said, "It looks like [SARS-CoV-2] is a virus that is very stimulatory to T cells, that most people have very good T cell responses to it, they are very activated. In B cell immunology a lot of the focus was on the spike, [but] when T cells look at this virus it looks like they are looking at bits of almost the entirety of the virus, with many different parts recognised ...

"They look rather durable, and they seem to be getting made in virtually all exposed people, from heavily infected hospitalised people to even PCR [polymerase chain reaction] negative household contacts of cases.”

At the same briefing Mala Maini, professor of viral immunology at University College London, said that it was "really important and exciting" that emerging studies were showing that T cells are being generated and may last much better than antibodies. However, she said that we need to think about T cells "working in tandem with antibodies and the B cells that make those antibodies."

She explained, "It's a complex army, the immune system, and [these cells] need to coordinate together to make the best immune response. It's important to remember that even very small amounts of antibodies can still potentially be very protective and that the B cells that make them, particularly if they are getting the right help from $\mathrm{T}$ cells, can be boosted again as soon as they encounter the virus and can then start to expand and make more antibodies.

"You can think of the antibodies as missiles that are sent out as a first line of protection, but you really need the factories that make those missiles - the plasma B cells-and also the other soldiers-the T cells-that can help the production of the antibodies and also some specialised killer T cells (CD8) that can directly recognise and eliminate infected cells.”

\section{Should we be testing for $T$ cell responses?}

Altmann said that there was enormous emphasis on antibody testing at the beginning of the pandemic but that the "caveat now is that we see that it is not as reliable a measure of prior exposure as we first thought it was, because some people may have waning antibody levels by eight or 10 weeks." However, he added that "at the moment we do not have the wherewithal to roll out [T cell] analysis on a wide scale.”

Mala concluded, "In terms of the capacity to use T cells as an additional marker for prior infection, it's an interesting idea but it's a long way from being a reality, and measuring T cells is a lot more complex than antibodies. Having said that, there is one test out there that does that for [tuberculosis] - the Quantiferon test relies on T cell reactivity-so there is a precedent for developing that.

"But I think we need to understand a lot more first, experimentally, in terms of how protective these T cells are and how feasible it would be to use them as an additional test."

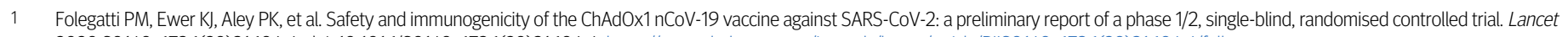
2020;S0140-6736(20)31604-4. doi: 10.1016/S0140-6736(20)31604-4. https://www.thelancet.com/journals/lancet/article/PIIS0140-6736(20)31604-4/fulltext.

2 Mahase E. Covid-19: Oxford team begins vaccine trials in Brazil and South Africa to determine efficacy. BMJ2020;369:m2612. doi: 10.1136/bmj.m2612 pmid: 32601063

3 Zhu FC, Guan XH, Li YH, et al. Immunogenicity and safety of a recombinant adenovirus type-5-vectored COVID-19 vaccine in healthy adults aged 18 years or older: a randomised, double-blind, placebo-controlled, phase 2 trial. Lancet2020;S0140-6736(20)31605-6. doi: 10.1016/S0140-6736(20)31605-6. https://www.thelancet.com/journals/lancet/article/PIIS0140-6736(20)31605-6/fulltext.

4 CanSino Biologics. Recombinant novel coronavirus vaccine (adenovirus type 5 vector) received military specially-needed drug approval. 29 Jun 2020 . https://www1.hkexnews.hk/listedco/listconews/sehk/2020/0629/2020062900123.pdf.

5 Kramer AE. Russia sets mass vaccination for October after shortened trial. New York Times 2020 Aug 2. https://www.nytimes.com/2020/08/02/world/europe/russia-trials-vaccine-October.html.

6 Barnes JE. Russia is trying to steal virus vaccine data, Western nations say. New York Times 2020 Jul 16. https://www.nytimes.com/2020/07/16/us/politics/vaccine-hacking-russia.html.

7 Sewell HF, Agius RM, Stewart M, Kendrick D. Cellular immune responses to covid-19. BMJ 2020;370:m3018. doi: 10.1136/bmj.m3018 pmid: 32737031

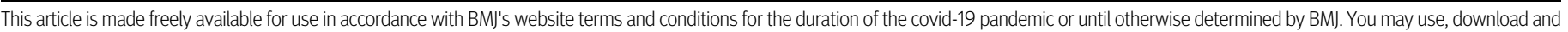
print the article for any lawful, non-commercial purpose (including text and data mining) provided that all copyright notices and trade marks are retained. 